\title{
Constrictive pericarditis complicating cardiac transplantation
}

\author{
Affan Umer ${ }^{1 *}$, Nauman Khalid ${ }^{2}$, Lovely Chhabra², Sarfaraz Memon² and David H. Spodick ${ }^{3}$
}

\begin{abstract}
Constrictive pericarditis is a disease characterized by progressive pericardial fibrosis. If left untreated it can lead to progressive heart failure and can be severely disabling. Medical management with non-steroidal anti-inflammatory drugs in combination with colchicine is promising in the acute phase of the disease but for more chronic cases pericardiectomy offers the best chance for hemodynamic recovery. Constrictive pericarditis after cardiac transplantation is a rare phenomenon. Current literature suggests that early pericardiectomy may be the most effective treatment in this subset of patients as well.
\end{abstract}

Keywords: Constrictive pericarditis, Pericardiectomy, Cardiac transplant

\section{To the Editor}

We read with great interest the recently published article byZhu et al. in the Journal of Cardiothoracic Surgery [1]. The authors have provided valuable insight regarding the role of pericardiectomy in constrictive pericarditis. Their mortality rate of $5.4 \%$ falls on the lower end of the spectrum in reported literature and their one year survival rate of $92 \%$ speaks volume of the excellent results that can be achieved in high volume centers [1]. However, we wish to highlight a few important points relevant to the article.

A relatively newer and less known development of constrictive pericarditis is seen recently after cardiac transplantation. This is an unusual presentation as the transplanted heart is believed to be free of any pericardial tissue. The data on this entity is very limited but judging from the few published case reports, pericardiectomy offers the only chance of successful physiologic recovery in this subset of patients [2,3]. We would like to inquire whether Zhu and colleagues encountered patients with post cardiac transplant constrictive pericarditis in their cohort in the subgroups including indeterminate $(n=106$ patients) and post-surgery ( $n=19$ patients) as indicated in Table one of their manuscript [1].

\footnotetext{
* Correspondence: affan.umer.83@gmail.com

'Department of Surgery, Saint Francis Hospital and Medical Center, University of Connecticut Health Center, Hartford, CT, USA

Full list of author information is available at the end of the article
}

Pericardiectomy is a well established treatment for sub acute to long-standing constrictive pericarditis [4]. However, a subset of patients affected with acute constrictive pericarditis may only experience transient constriction and may benefit from only medical management with non-steroidal anti-inflammatory drugs and/or colchicine for 2 to 3 months duration. We wonder if a similar therapeutic algorithm was used in their study especially in the patients presenting with acute constrictive physiology? We would appreciate if the authors could share their invaluable experience on these subgroup of patients.

\section{Competing interests}

Dr. David Spodick receives royalties from his textbook, "The Pericardium: A Comprehensive Textbook (Fundamental and Clinical Cardiology), Marcel Dekker, New York 1997".

\section{Authors' contributions}

$\mathrm{AU}$ was responsible for the initial draft. AU, NS, LC, SM, DS were responsible for all subsequent revisions. All authors approved the final submitted draft of the manuscript.

\section{Acknowledgement}

We would like to thank Dr Sarah Aftab Ahmad, Department of Surgery, Texas Tech University Health Sciences Center, Lubbock, USA for proof reading and editing the manuscript.

\section{Author details \\ ${ }^{1}$ Department of Surgery, Saint Francis Hospital and Medical Center, University of Connecticut Health Center, Hartford, CT, USA. ${ }^{2}$ Hartford Hospital, University of Connecticut Health Center, Hartford, CT, USA. ${ }^{3}$ Saint Vincent Hospital, University of Massachusetts Medical School, Worcester, MA, USA.}

Received: 16 July 2015 Accepted: 3 August 2015

Published online: 25 August 2015

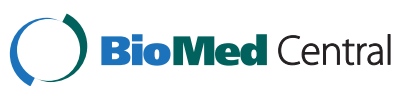

(c) 2015 Umer et al. Open Access This article is distributed under the terms of the Creative Commons Attribution 4.0 International License (http://creativecommons.org/licenses/by/4.0/), which permits unrestricted use, distribution, and reproduction in any medium, provided you give appropriate credit to the original author(s) and the source, provide a link to the Creative Commons license, and indicate if changes were made. The Creative Commons Public Domain Dedication waiver (http://creativecommons.org/publicdomain/zero/1.0/) applies to the data made available in this article, unless otherwise stated. 


\section{References}

1. Zhu P, Mai M, Wu R, Lu C, Fan R, Zheng S. Pericardiectomy for constrictive pericarditis: single-center experience in China. J Cardiothorac Surg. 2015;10:34.

2. Roca J, Manito N, Castells E, Miralles A, Mauri J, Saura E, et al. Constrictive pericarditis after heart transplantation: report of two cases. J Heart Lung Transplant. 1995;14:1006-10.

3. Bansal R, Perez L, Razzouk A, Wang N, Bailey L. Pericardial constriction after cardiac transplantation. J Heart Lung Transplant. 2010;29:371-7.

4. Maisch B, Seferovic PM, Ristic AD, Erbel R, Rienmuller R, Adler $Y$, et al. Task force on the Diagnosis and Management of Pericardial Diseases of the European Society of Cardiology. Guidelines on the diagnosis and management of pericardial diseases: executive summary. Eur Heart J. 2004;25:587-610.

\section{Submit your next manuscript to BioMed Central and take full advantage of:}

- Convenient online submission

- Thorough peer review

- No space constraints or color figure charges

- Immediate publication on acceptance

- Inclusion in PubMed, CAS, Scopus and Google Scholar

- Research which is freely available for redistribution 